\title{
MOBILE GIS: A TOOL FOR INFORMAL SETTLEMENT OCCUPANCY AUDIT TO IMPROVE INTEGRATED HUMAN SETTLEMENT IMPLEMENTATION IN EKURHULENI, SOUTH AFRICA
}

\author{
B. T. Mokoena ${ }^{a, *}$, W. Musakwa ${ }^{a}$ \\ a Dept. of Town and Regional Planning, University of Johannesburg, Cnr Siemert and Beit Streets, Doornfontein, South Africa - \\ balesengmokoena211@gmail.com,wmusakwa@uj.ac.za \\ Commission II, Theme Session 17 Smart \\ Cities
}

KEY WORDS: Mobile GIS, occupancy audit, informal settlements, integration, Ekurhuleni

\begin{abstract}
:
Upgrading and relocating people in informal settlements requires consistent commitment, good strategies and systems so as to improve the lives of those who live in them. In South Africa, in order to allocate subsidised housing to beneficiaries of an informal settlement, beneficiary administration needs to be completed to determine the number of people who qualify for a subsidised house. Conventional methods of occupancy audits are often unreliable, cumbersome and non-spatial. Accordingly, this study proposes the use of mobile GIS to conduct these audits to provide up-to-date, accurate, comprehensive and real-time data so as to facilitate the development of integrated human settlements. An occupancy audit was subsequently completed for one of the communities in the Ekurhuleni municipality, Gauteng province, using web-based mobile GIS as a solution to providing smart information through evidence based decision making. Fieldworkers accessed the off-line capturing module on a mobile device recording GPS coordinates, socio-economic information and photographs. The results of this audit indicated that only $56.86 \%$ of the households residing within the community could potentially benefit from receiving a subsidised house. Integrated residential development, which includes fully and partially subsidised housing, serviced stands and some fully bonded housing opportunities, would then be key to adequately providing access to suitable housing options within a project in a post-colonial South Africa, creating new post-1994 neighbourhoods, in line with policy. The use of mobile GIS therefore needs to be extended to other informal settlement upgrading projects in South Africa.
\end{abstract}

\section{INTRODUCTION}

Urbanisation is a phenomenon that has been growing in recent decades in the global south (Turok \& Borel-Saladin, 2014), manifesting itself in the form of informal settlements (Freire, et al., 2014). It is said that Africa is urbanising rapidly from a $15 \%$ growth in 1960 to $40 \%$ in 2010 (Freire, et al., 2014). According to UN-Habitat (2010), $60 \%$ of Africans will be living in cities by 2050 , and triple in the forthcoming 50 years. This will change the form of regions and mandate policy makers to maximise on urbanisation towards sustainable and inclusive growth (UNHabitat, 2015). The New Urban Agenda (UN-Habitat, 2015) furthermore calls for policy makers to shift their mind sets from viewing urbanisation as a problem but rather as a tool for development. The current model of urbanisation is not sustainable, nor is it adequate for social and economic prosperity (UN-Habitat, 2015). The strategic and integrated approach taken in the new Strategic Plan for 2014-2019, recommends that we apply a more systemic approach that goes beyond addressing the symptoms of urbanisation, but linking urbanization and human settlements to sustainable development by focusing on the prosperity, livelihoods and employment of the greater population (UN-Habitat, 2015). This will be done by paying attention to the basic needs of the millions of people living in poverty within towns and cities, as well as urban slums (UN-Habitat, 2015).

Unlike Africa, other parts of the world's urbanisation patterns are normally led by industrialisation and economic development; defined by the increase of productivity from proximity and the concentration of activities, confirming a relationship between per capita income and urbanisation (Freire, et al., 2014). Africa's urbanisation patterns however indicate a migration of lower level income groups and less investment of infrastructure (Freire, et al., 2014). This poses a challenge for cities that are unable to accommodate large population influxes that ensure favourable living environments (Freire, et al., 2014).

Migration and urbanisation as described in the Migration and Urbanisation in South Africa Report (2006) is often observed as the result of raptures of economic exploitation, political tension, environmental disasters or violence. South Africa has a particular history, which informed its migration and urbanisation patterns over the past few decades, known as apartheid. The apartheid system historically endeavoured to restrict and control the population movement as well as its settlements patterns in the rural areas or Bantustans (Turok \& Borel-Saladin, 2014). Thus tyrannical laws were enforced on people such as the welldocumented population control, Group Areas Act of 1950 (Act No. 41 of 1950) and pass law that caused impermanence in the urbanisation process (Turok \& Borel-Saladin, 2014; Harrison, et al., 2008; Zuma, 2013). These events resulted in inadequate urban planning in the urban areas which lead urban settlements into sprawling peri-urban areas (Harrison, et al., 2008). This also meant that people were forced to live in ethnically homogenous homelands with limited access to land, resulting in the transition from an agrarian to a cash-based rural economy in order to provide large numbers of labour migrants ${ }^{1}$ (Zuma, 2013).

This unique phenomenon of urbanisation has affected the housing sector drastically over the years, with the influx of people coming into major cities in South Africa, most of whom find themselves living in informal settlements (Huchzermeyer,

\footnotetext{
${ }^{*}$ Corresponding author

${ }^{1}$ Growth, transformation, reform: Emerging economies in the next decade (Zuma, 2013)
} 
2004). This posing a challenge for the state in how it deals with housing people in the low income bracket or with no income at all.

\section{THE DISCOURSE OF UPGRADING INFORMAL SETTLEMENTS PRE AND POST 1994}

The chronical of informal settlement upgrading policy in South Africa needs to be narrated for us to understand the context, which we find ourselves today. In Marais \& Ntema's (2013) reflection through the lens of Huchzermeyer (2004), discussions of this unfolds in a manner that suggests that until recently, policy had not been developed for the new post-apartheid government for informal settlement upgrading. 'Breaking New Ground': A comprehensive plan for the development of informal settlements was developed only in 2004, after the realisation that the housing subsidy scheme alone was not sufficient to deal with the large inflow of black people in informal settlements (Huchzermeyer, 2004). The upgrading of informal settlements was strongly opposed during the apartheid era, further enforced by the demolishing and forced removals of these settlements (Platzky \& Walker, 1985). The control of urbanisation which was abolished in 1985, saw the influx of people in many cities (Huchzermeyer, 2004). Controlled urbanisation was driven by the then government to control land development which meant that land was largely available for middle-income groups or white people and not for low-income households or black people (Huchzermeyer, 2004). The land that was made available for black people was mostly funded by loans provided by the National Housing Commission. The large influx of people by the early 1990 in the form of land invasions on open land across South Africa (Seekings, 1991) put pressure on the apartheid government to embark on large-scale upgrading of informal settlements (Marais \& Ntema, 2013). The Independent Development Trust (IDT) was then established around that time providing site-and service and settlement upgrading to approximately 100000 households across South Africa providing water, sanitation, electricity and ownership, packaged in the capital subsidy of R7 500 per household (Marais \& Ntema, 2013). The upgrading process by the IDT, Huchzermeyer (2004) agues and critics, where driven by the market orientated development approach (neo-liberalism) with very minimal community participation as well as a technocratic approach of a one size-fits-all, putting people on the periphery in greenfield projects. Stating that the new post-apartheid government had followed to a large extent in the same footsteps with its new housing policy (Huchzermeyer, 2004). With a once off capital subsidy, at the time, of R15 000 for people earning R0-800 per month focusing on the lowest income earners, working on a sliding scale, and providing R9 000 for people earning R2500R3500 per month (Huchzermeyer, 2004). Breaking New Ground together with its Informal Settlement Upgrading Programme introduced a concept of promoting social inclusion through community based subsidies and participatory planning of layouts, poverty eradication by securing tenure and assistant livelihoods through well located land and reduction of vulnerabilities through providing economic and social facilities (Huchzermeyer, 2006). These objectives focused on the rehabilitation of land for upgrading, moving away from the overemphasis of Greenfield development as well as focusing on mixed-income groups rather than just on low-income groups (Huchzermeyer, 2006; Marais \& Krige, 1999). Emphasising rather on the need for better-located mixed-income and mixeduse housing projects ${ }^{2}$.

\section{ENUMERATION OF INFORMAL SETTLEMENTS:}

The enumeration process is an important part of informal settlement upgrading, especially when there is no data that exists for a community. It is also useful to have data that is regularly updated. The purpose of enumeration is to provide basic information on all individuals and households (Karanja, 2010) in a particular settlement. This section highlights some of the challenges faced in different enumeration processes.

An informal settlement was enumerated in Nairobi, Kenya, organized by the inhabitants, to examine the detail and scale, depth and nature of poverty within the community (Karanja, 2010). It was immediately established that the experience gathered from this enumeration process, demonstrated that the way in which information is collected as well as who gathers it, is as important as the information itself (Karanja, 2010). This is because it influences not only the quality and detail of the data collection and its verification but the nature of the occupant's involvement with planning and implementation of informal settlement upgrading (Karanja, 2010). It was also found that the challenges and pressures faced in this enumeration process where from the people who were not residents of the community, wanting to get plots for friends or family members residing in other communities or for adult children living with them (Karanja, 2010).

In a another area, mapping and enumeration of informal Roma settlements, located in Serbia Southeastern Europe was conducted with the attempt to response to some of the housing challenges confronting the communities (Vuksanovic-Macura, 2012). This exercise was conducted several times over a number of years by non-governmental organisations and Roma associates. The settlements, as described by VuksanovicMacura's (2012), were characterised by very poor living conditions because of historic social exclusion and intolerance faced from formal communities (Vuksanovic-Macura, 2012). In her paper she also pointed out that the difficult housing challenges that these settlers faced had not been adequately addressed by national and local authorities, and therefore because of this, with the aim of assisting communities, mapping and enumeration initiatives were undertaken over the years for settlement upgrading, socio-economic empowerment purposes, to name a few (Vuksanovic-Macura, 2012).

The method used for enumeration and mapping were questioners on household information and about the physical house and plot. The mapping component described the extent of the settlement spatially. Photographs were also taken. The data gathered was entered into a spreadsheet programme and the maps were digitized, forming a database (Vuksanovic-Macura, 2012).

As a final reflection the Vuksanovic-Macura's (2012) paper highlighted that while the information gathered by the NGO's was good for the initial phase of a project, given the limited scope and funding, it was insufficient if procedures based on the law was required. This is because official documentation is needed should an upgrading project require formal administrative procedures by way of producing an urban plan, legalizing illegally constructed houses and initiating court procedures to transfer ownership (Vuksanovic-Macura, 2012).

\footnotetext{
${ }^{2}$ National Development Plan: Vision for 2030, (2011)
} 
It is found that the use of Geographic Information Systems (GIS), according to Chitekwe-Biti, et al., (2012), has transformed the extent in which information can be used for planning purpose across the world. Internationally there has been a great development of skills allowing communities to effectively and accurately link information collected during household level enumerations with mapping (Chitekwe-Biti, et al., 2012). Therefore GIS has created the possibility of linking social data with spatial data (Chitekwe-Biti, et al., 2012).

Consequently, the aim of this study is to use smart mobile GIS, to enumerate and conduct an occupancy audit in Ulana informal settlement, Ekurhuleni, South Africa. The remainder of the paper is structured as follows; the next section provides a description of the study area, Ekurhuleni, followed by the methodology, which describes how the occupancy audit was conducted. Lastly the results and discussion are presented.

\section{STUDY AREA: EKURHULENI AND ULANA SETTLEMENT}

The Ekurhuleni Region is a Metropolitan made up of an amalgamation of nine towns accompanied by its townships ${ }^{3}$. The region was historically known as Eats Rand. Each town consisting of suburbs, industrial areas and the black residential areas attached to them (Bonner, et al., 2012; City of Ekurhuleni, 2013). It has a total surface area of $1975 \mathrm{~km}^{2}$ with a population of 3178870 million (City of Ekurhuleni, 2013). It has a strong manufacturing sector and is regarded as the transportation hub of South Africa, having the busiest airport in Africa ${ }^{4}$ and as such seeking towards branding itself an Aerotropolice. It also has South Africa's largest railway hub in Germiston, linking it to all major population centres and ports in the Southern Africa region ${ }^{4}$.

Ulana Settlement is an informal settlement located in Boksburg, Ekurhuleni (Figure 1).

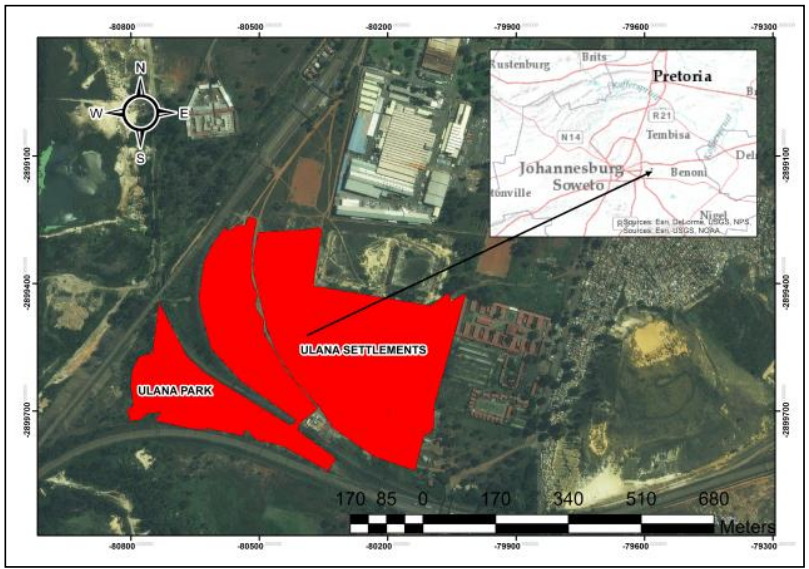

Figure 1: Location of Ulana Settlement

Ulana has a population of 3092 households according to the recent occupancy audit completed. Ekurhuleni has the second highest number of households living in informal settlements in the country ${ }^{5}$, with a total of 119 settlements and a population of

${ }^{3}$ Townships in South Africa often referring to the location where the black people reside.

4 Ekurhuleni Metropolitan Municipality: IDP, Budget \& SDBIP, 2013/14-2015/16 (2013) approximately 160000 households $^{6}$ in need of being upgraded or relocated.

While enumeration of informal settlements remain an important part of any upgrading project, this paper sets to demonstrate how web based mobile GIS can be used as a tool for enumeration, to foster integrated human settlements. Given the challenges of urbanisation in cities of the Global South, and more specifically within the unique context of South Africa (and Ekurhuleni), the chronicles of upgrading informal settlements pre and post 1994 proved (and still proves) to be challenging.

\section{METHODOLOGY}

A web-based Mobile GIS tool was used to conduct the occupancy audit in Ulana, as it is often difficult and cumbersome with other techniques. Data collection was conducted from 13 March 2015 to 30 March 2015. A follow up data collection session was done on April 18-19 for occupant's who were unavailable in March. A GPS was used to collect the location of the dwelling units (DU) whilst an android-based tablet was used to collect attributes of the DU, images as well as the household attributes. This information was stored and synchronised in a server (Figure 2).

During data collection each household and dwelling unit was allocated a barcode to ensure that repetition and redundancy was eliminated. In addition, a drop standard down menus and validation rules were put in place as quality assurance (Figure 3 ).

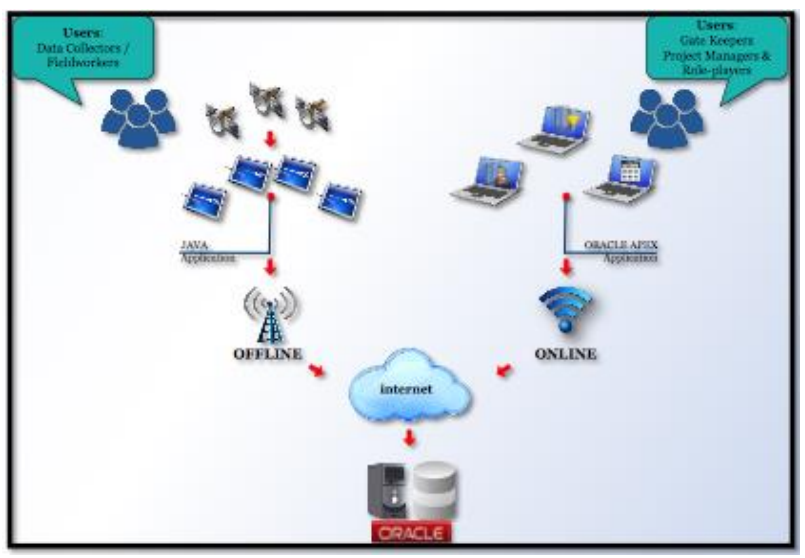

Figure 2: Mobile GIS Architecture

There were minor challenges experienced during data collection such as some members of the households without identification documents. In addition it was difficult to obtain proof of income document.

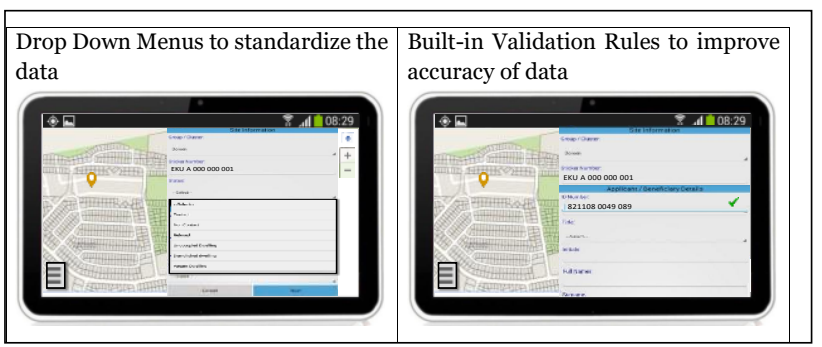

Figure 3: Data Capturing Menus

\footnotetext{
${ }^{5}$ South Africa: Informal Settlements Status Report, 2012

${ }^{6}$ EMM: Urban Settlement Grant (2012)
} 


\subsection{Data analysis}

ArcGIS 10.3 was used to join the location and the attribution data for spatial analysis. Density analysis was done using the spatial analysist extension to determine the number of DU per $2500 \mathrm{~m}^{2}$. For the occupancy audit analysis descriptive statistical analysis was carried out on demographic attributes such as citizenship, gender, income, dependants and whether one received a subsidised house before from the municipality or government. The demographic profile would then be used to determine if a household qualifies for a housing subsidy.

\section{RESULTS AND DISCUSSION}

\subsection{Densities, Ulana Settlement}

Figure 4 shows the built up area densities in Ulana Settlement, demonstrating the number of dwelling units (shacks) per 2 $500 \mathrm{~m}^{2}$. Figure 4 shows that Ulana has very high densities in some sections of $>48 \mathrm{du} / 2500 \mathrm{~m}^{2}$. At least $70 \%$ of Ulana has densities of above 25 units per 2500sqm representing very high densities. These densities are well above the Ekurhuleni Regional Spatial Development Framework (2015) permissible densities of 60 dwelling units per hector for single and semi-detached housing typologies. Therefore it appears households in Ulana are living under deplorable and crowded conditions.

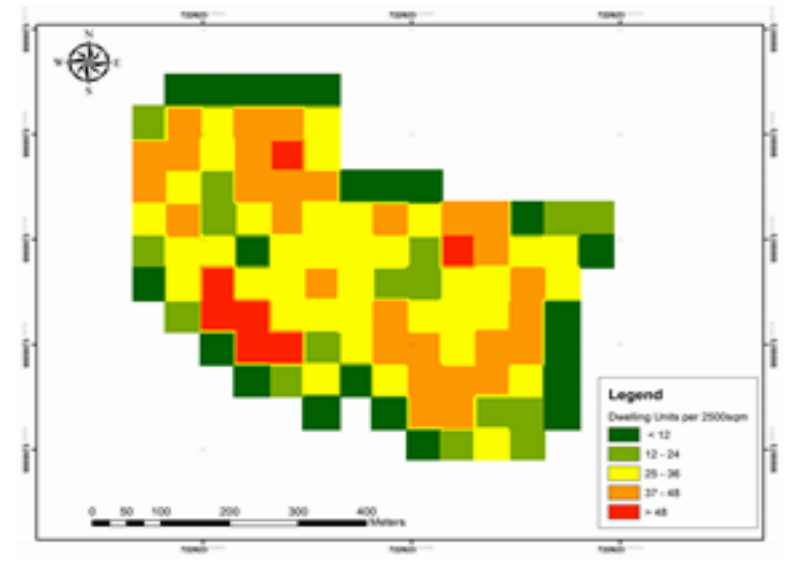

Figure 4: Ulana Settlement Densities

These very high densities in Ulana further negatively affects the quality of life as well quality of place for its inhabitants. The living conditions in which informal settlers live are well described by Fanon (1961) who went on to write that 'It is a world without spaciousness; men live there on top of each other.. built one on top of the other.. a hungry town, starved of bread, of meat, of shoes, of coal, of light.. a crouching village, a town on its knees, a town wallowing in mire'. Similarity the dwelling units in Ulana are built close to each other as well as the poor material used exposes them to fire hazards. The use of candles, paraffin or gas in small, crowded spaces, usually results in fires that can quickly spread in crowded areas such as Ulana. Health conditions continue to deteriorate in informal settlements due to the squalid and deplorable conditions. Dewan et al. (2012) have noted that unplanned urban growth can lead to invasive disease infections such as the dengue infection. Furthermore, there have been reports of infectious diseases such as typhoid fever in Gauteng fever owing to the squalid conditions; meanwhile there has been diarrhoea outbreaks recorded over the past years in informal settlements (SA News 2016; Govender, Barnes \& Peiper, 2011). Similarly, the high densities also pose a health risk as they are a fertile breeding ground of pests such as cockroaches and rats in South African cities (ENCA, 2014). The Ekurhuleni Municipality acknowledges that it has a rat problem as a result of informal settlements such as Ulana.

In addition the high densities combined with the poor material used for building in informal settlements expose residents to weather elements such as rain, cold weather and wind. The poor storm water drainage and waste disposal systems in Ulana settlement also result in high levels of vermin and mosquitos, causing disease and infection to spread rapidly. Poor access to good sanitation and clean water makes it difficult for people to maintain a good hygiene standard. The lack of good lighting on roads and pathways exposes individuals to crime and violence. There is also a lack of public and private spaces for recreation in Ulana, which often results in substance abuse, and a lack of sufficient food leading to malnutrition (HDA, 2014). Informal settlement upgrading then becomes imperative, in order to improve the quality of life and space of people.

\subsection{Occupancy Audit, Ulana Settlement}

The audit conducted revealed that Ulana Settlement has 3092 households residing within the community, with a total population of 7031 . The total population includes the head of household, spouses as well as dependence. Crucial to the project is knowing how many people qualify for subsidised housing. Table 1 illustrates that according to the findings, 1758 households potentially qualify for subsidised housing. Which means that only $56.89 \%$ would potentially be allocated houses.

\begin{tabular}{|l|c|c|}
\hline Category & Quantity & Percentage \\
\hline Potential Beneficiaries & 1758 & $56.89 \%$ \\
\hline Single with no dependents & 834 & $26.97 \%$ \\
\hline Income exceeds R3500 & 396 & $12.8 \%$ \\
\hline Non SA Citizens & 40 & $1.29 \%$ \\
\hline Previously approved & 64 & $2.0 \%$ \\
\hline $\begin{array}{l}\text { Total Number of } \\
\text { Households }\end{array}$ & $\mathbf{3 0 9 2}$ & $100 \%$ \\
\hline
\end{tabular}

Table 1: Occupancy Audit

To determine potential qualifiers for a housing subsidy, the identity document number of respondents was filtered through the Housing Subsidy System (HSS), which is a database and information system that is linked to the National Housing Database and provides information on individual beneficiaries who have applied for housing. The National Department of Human Settlements is the overseer of the HSS and the Provincial Department of Human Settlements are responsible for managing the database. Recently some local municipalities were also given responsibilities for the administrating and managing beneficiary applications. Housing officials are able to log on to the system and check the names of applicants on its database with those of the national database to see if applicants qualify for homes based on the qualification criteria of the housing programmes ${ }^{7}$. The identity document, monthly household income, dependents and age are some of the determining factors for a housing subsidy. This information was all gathered to determine potential beneficiaries. Officials will verify these beneficiaries as the final process.

The advantages of applying smart technology to collect data for occupancy audit is that it is, reliable, up-to-date, flexible and it

\footnotetext{
${ }^{7}$ National Housing Code: Vol 3 Individual subsidies
} 
facilitates informed decision making as opposed to traditional cumbersome techniques such as use of paper based questionnaires. At present the data that currently exists for informal settlements for the Ekurhuleni Local Municipality is outdated and only contains the approximate number of households in each settlement without detailed demographic attributes as collected using the smart mobile GIS. This unfortunately becomes difficult for the Human Settlements Department to plan adequately for informal settlement projects and may lead to waste of financial resources. Having accurate and updated information, that also contains potential beneficiaries information, will enable the department to plan more efficiently for its people as well as optimising resources. For instance the In-Situ upgrading project for Ulana informal settlement, named Balmoral Extension four (Figure 5) resulted in an adoption of a layout plan with 1092 opportunities in the form of single stands, zoned Residential 1, each Erf size being $78 \mathrm{~m}^{2}$.

It is important to mention that the Township Layout for Balmoral Extension Four was (Figure 5) completed prior to the audit and therefore, although well located, the number of stands available will not be sufficient to accommodate the needs of the community. Hence the use of smart mobile GIS tools to collect attributes of informal settlements is an invaluable tool in evidence based upgrading of informal settlements for future projects.

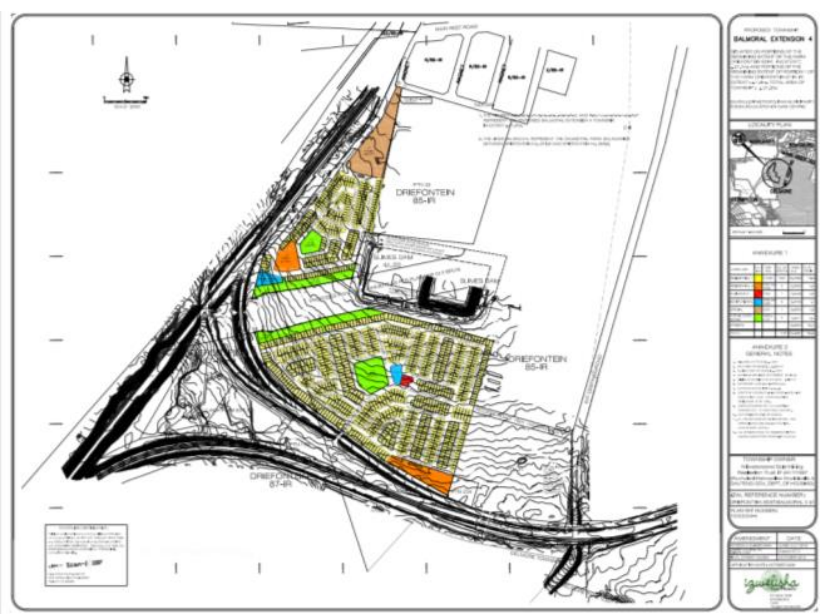

Figure 5: Balmoral Ext 4 layout

\section{THE PROFITS OF INTEGRATED HUMAN SETTLEMENTS}

The United Nations Housing Policy Guidelines For Developing Countries (1976) in its definition for housing, stated by an Ad Hoc Expert Group in 1962, that 'housing is not 'shelter' or 'household facilities' alone, but comprises a number of facilities, services and utilities which link the individual and his family to the community, and the community to the region in which it grows and progresses" Another Ad Hoc Group in 1970 concluded that "In fulfilling of social needs, housing plays both a direct and indirect role, and both roles are decisive. In its direct role housing serves as the area where the individual becomes capable of experiencing community and privacy, social well-being, and shelter and protection against hostile physical forces and disturbances. In its indirect role housing serves as the area where

${ }^{8}$ Cosmo City: An integrated development located in Johannesburg, South Africa can be viewed as an example, see: http://www.joburg.org.za.

${ }^{9}$ Spatial Planning and Land Use Management Act 16 of 2013 (SPLUMA) on spatial justice; Part 3 of The National Housing Code: Integrated an abundant supply of social relationship and services are accessible, such as places for social intercourse, education, sports, social welfare and health protecting services, shopping and transportation". These definitions illustrate and suggest that housing is very complex and therefore solutions on how best to deliver housing needs to be continually sought.

The conventional way of designing for low income neighbourhoods is unfortunately not ideal, if the needs of the community where to be comprehensively addressed. The reality according to the findings is that informal settlements are represented by a diverse group of people and should be planned as such. Integrated development translates this diversity, by providing opportunities for fully subsidised, partially subsidised, serviced stands, rental and bonded housing; creating 'new post 1994 neighbourhoods'.

The benefits that follow integrated development create openings for 'entangled' spaces', spoken of and defined by Nuttall (2009) as 'A condition of being twisted together or entwined, it speaks of an intimacy gained, even if it was resisted, or ignored or uninvited. It is a term which may gesture towards a relationship or a set of social relationships that is complicated, ensnaring, in a tangle, but which also implies a human foldedness'. Integration through strong planning interventions would then eliminate social injustice within the urban space (Oelofse, 2003), encouraging policy makers to view urbanisation as a tool for development and not as a problem (UN Habitat, 2015).

Even though the integrated approach is not a new concept ${ }^{8}$, what this paper introduces is a tool that would improve implementation of this approach, within the informal settlement upgrading program. The solution is therefore the collection of attribute data of informal settlements which helps in the development of reliable, evidence based planning. The use of mobile GIS therefore needs be extended to other informal settlement upgrading projects in South Africa as well as other cities in the global south. The data collected using smart mobile GIS tools is not only useful for enumeration and beneficiary administration but goes on to assist local government in implementing social, economic and spatial integration in line with policy ${ }^{9}$. Calling for the need to place people in well located areas. This will allow planners to plan efficiently. The use of smart technology also demonstrates that successful planning for housing delivery is not rhetoric but is based on sound information from communities concerned. However training is required to ensure the successful usage of smart mobile GIS tools.

\section{CONCLUSION}

Although the challenges faced by cities in the global south cannot be solved in one day, this paper sought to provide a solution to the challenge of urbanisation in Ekurhuleni South Africa, manifesting itself through the form of informal settlements within its jurisdiction. A case study was used to demonstrate how the current model of settlement planning proved to be insufficient to comprehensively accommodate the needs of a diverse community. The paper demonstrated how integrated development can be implemented through the use of web based mobile GIS, by determining the number of potential qualifiers for

Residential Development Programme, Breaking New Ground (2004) and Chapter Eight of the National Development Plan: Vision 2030 (2011) 
subsidised housing in each informal settlement upgrading project, in order to assess the divers needs of communities.

\section{REFERENCES}

Bonner, P., Nieftagodien, N. \& Mathabatha, S., 2012. Ekurhuleni: The making of an urban region. Johannesburg: Wits University Press.

Chitekwe-Biti, B., Mudimo, P. \& Nyama, G. M., 2012. Developing an informal settlement upgrading protocol in Zimbabwe - the Epwarth story. Environment \& Urbanisation, 24(1), pp. 131-148.

City of Ekurhuleni, 2005. Ekurhuleni Growth Development Strategy 2055, Germiston: Directorate: Communications and Marketing.

City of Ekurhuleni, 2013. Ekurhuleni Metropolitan Municipality: IDP, Budget \& SDBIP, 2013/14-2015/16, Germiston: Directorate: Communication and Marketing.

City of Ekurhuleni, 2015. RSDF. [Online] Available at: http://www.ekurhuleni.gov.za/rsdf-1 [Accessed 27 February 2016].

City of Johannesburg, 2008. Cosmo City is a thriving suburb. [Online]

Available

at:

http://joburg.org.za/index.php?option=com_content\&task=view \&id $=2089 \&$ Itemid $=168$

[Accessed 28 December 2015].

Dawan, A., Yamaquchi, Y. \& Ziaur Rahman, M., 2012. Dynamics of land use/cover changes and the anlaysis of landscap fragmentation in Dhaka Metropolitan. GeoJournal, 77(3), pp. 315-330.

ENCA, 2013. Ekurhuleni fights rat problem. [Online] Available at: https://www.enca.com/south-africa/ekurhulenifights-rat-problem

[Accessed 15 March 2016].

ENCA, 2014. Joburg to spend, illions to fight rat epidemic. [Online]

Available at: https://www.enca.com/joburg-spend-millionsfight-rat-epedemic

[Accessed 16 March 2016].

Fanon, F., 1961. The Wretched of the Earth. London: Pinguin Group.

Freire, M. E., Lall, S. \& Leipziger, D., 2014. Africa's Urbanization: Challenges and Opportunities, Washington: The Growth Dialogue.

Govender, T., Barnes, J. M. \& Piper, C. H., 2011. Contribution of water pollution from inadedequate sanitation and housing quality to diarrheal disease in low-cost housing settlements of Cape Town, South Africa. American journal of public health, 101(7), pp. 4-9.

Harrison, P., Todes, A. \& Watson, V., 2008. Planning and Transformation: Learning from the Post-Apartheid Experience. Lanodon and New York: Routledge.

Housing Development Agency, 2012. South African: Informal Settlements Status, s.1.: s.n.

Huchzermeyer, M., 2004. Unlawful occupation, informal settlements and Urban Policy in South Africa and Brazil. Trenton: Africa World Press.

Huchzermeyer, M., 2006. The new instrument for upgrading informal settlements in South Africa: Contributions and constraints. In: M. Huchzermeyer \& A. Karam, eds. Infromal Settlements: A perepetual challange. Cape Town: UCT Press, pp. 41-61.

Karanja, I., 2010. An enumeration and mapping of infromal settlements in Kisumu, Kenya, implemented by their inhabitants. Environment \& Urbanisation, 22(1), pp. 217-239.
Marais, L. \& Krige, S., 1999. Post-apartheid housing policy and initiatives in South Africa: Reflections on the BloemfonteinBotshabelo-Thaba 'Nchu Region. Urban Forum, 10(2), pp. 115136.

Marais, L. \& Ntema, J., 2013. The upgrading of an informal settlement in South Africa: Two decades onwards. Habitat International, Volume 39, pp. 85-95.

Nuttall, S., 2009. Entanglement: Litrary and cultural reflections on post-aprtheid. Johannesburg: Wits University Press.

Oelofse, M., 2003. Social Justice, Social Intergration and the Compact City: Lessons from Inner City of Johannesburg. In: P. Harrison, M. Huchzermeyer \& M. Mayekiso, eds. Confronting Fragmentation: Housing and Urban Development in a Democratising Society. Cape Town: Cape Town Press, pp. 88121.

Platzky, L. \& Walker, C., 1985. The surplus people: Forced removals in South Africa. Johannesburg: Raven Press.

Republic of South Africa, 2004. "Breaking New Ground": A comprehensive plan for the development of sustainable human settlements, s.l.: s.n.

Republic of South Africa, 2009. National Housing Code: Part 3 Upgrading Informal Settlement, s.1.: s.n.

Republic of South Africa, 2011. National Development Plan: Vision of 2030 - Chapter 8, Pretoria: Government Printers. Republic of South Africa, 2011. The National Development Plan: Vision 2030, Pretoria: Governement Printers.

Republic of South Africa, 2012. Ekurhuleni Metropolitan Municipality: Urban Settlement Grant, s.l.: s.n.

Republic of South Africa, 2013. Spatial Planning and Land Use Management Act 16 of 2013, Pretoria: Goverenment Printers.

SA News, 2015. Gauteng on alert after four cases of typhoid fever.

[Online]

Available at: http://www.sanews.gov.za/south-africa/gautengalert-after-four-cases-typhoid-fever

[Accessed 16 March 2016].

Seekings, J., 1991. Township resistance in 1980s. In: M. Swilling, R. Humphries \& K. Shubane, eds. Apartheid City in Transition. Cape Town: Oxford University Press, pp. 290-308.

Stats-SA, 2006. Migration and Urbanisation in South Africa Report, Pretoria: Republic of South Africa.

Turok, I. \& Borel-Saladin, J., 2014. Is urbanisation in South Africa on a sustainable trajectory? Development Southern Africa, 31(5), pp. 675-691.

UN-Habitat, 2010. State of the World's Cities 2010/2011: Bridging the Urban Divide, Nairobi: UN Habitat.

UN-Habitat, 2015. Urban Solutions, Nairobi: UN-Habitat.

UN-Habitat, 2015. Urbanization for Prosperity, Nairobi: UN Habitat.

United Nations, 1976. Housing Policy Guidelines for Developing Countries, New York: UN-Habitat.

Vuksanovic-Macura, Z., 2012. The mapping and enumeration of informal Roma settlements in Serbia. Environment \& Urbanisation, 24(2), pp. 685-705.

Zuma, N., 2013. Rural-urban Migration in South Africa. Haikou, Economic Policy Forum. 